\title{
ANALISIS DETERMINAN TINGKAT CASH HOLDING PERUSAHAAN PROPERTY DAN REAL ESTATE YANG TERDAFTAR DI BURSA EFEK INDONESIA PERIODE 2015-2019
}

\author{
Siti Masrifah' ${ }^{1}$, R. Bambang Dwi Wiryanto ${ }^{2}$, Fauziyah ${ }^{3}$ \\ Universitas PGRI Adi Buana Surabaya ${ }^{1,2,3}$ \\ Masrifah9996@gmail.com
}

\begin{abstract}
ABSTRAK
Untuk menguji dan mendapati dampak dari tiap variabel terhadap peraturan cash holding (kas ditangan) di industri properti yang tercatat pada Bursa Efek Indonesia (BEI) 2015-2019 ialah tujuan penelitian ini. Sebanyak 20 perusahaan properti menjadi sampel dalam penelitian. Kajian data yang dimanfaatkan yaitu, regresi linier berganda menggunakan metode kuantitatif dengan program SPSS release 23.0. Hasil penelitian : (1) cash flow, firm size, dan cash corversion cycle secara parsial tidak berdampak signifikan pada cash holding; (2) net working capital, growth opportunity, leverage, dan board size secara parsial berdampak signifikan atas cash holding; (3) cash flow, net working capital, firm size, growth opportunity, leverage, board size, dan cash conversion cycle secara simultan berdampak pada cash holding (kas ditangan) perusahaan property dan real estate yang tercatat pada Bursa Efek Indonesia (BEI) 2015-2019.

Kata kunci: Cash Holding, Net Working Capital, Cash flow, Growth Opportunity, Firm Size

ABSTRACT

To test and find the impact of each variable on cash holding regulations in the property industry listed on the Indonesia Stock Exchange (IDX) 2015-2019 is the purpose of this research. A total of 20 property companies become samples in research. The study of the data utilized is, multiple linear regression using quantitative methods with SPSS release 23.0 program. The results of the research: (1) cash flow, firm size, and cash corversion cycle are partially no significant impact on cash holding; (2) Net working capital, growth opportunity, leverage, and board size partially impact on cash holding; (3) Cash flow, net working capital, firm size, growth opportunity, leverage, board size, and cash conversion cycle are simultaneously impacted by cash holding (cash-in) of property and real estate companies listed on the Indonesia Stock Exchange (IDX) 2015-2019.
\end{abstract}

Keyword: Cash Holding, Net Working Capital, Cash flow, Growth Opportunity, Firm Size 


\section{PENDAHULUAN}

Salah satu bidang yang memajukan ekonomi saat ini yaitu properti, dilihat dari tingginya tingkat investasi masyarakat dalam menanamkan modalnya pada bidang ini. Pesatnya investasi pada properti bukan hanya terjadi di kota besar saja, misalnya Jabotabek, akan tetapi juga pada daerah lain di luar pulau jawa.

Berkaitan dengan masih tingginya minat investor untuk menginvestasikan dananya pada properti serta tingginya daya saing, maka perusahaan yang berkecimpung di bidang properti harus bisa mengendalikan anggaran dana untuk operasionalnya. Perhitungan yang tidak tepat menyebabkan perusahaan memiliki kinerja buruk. Sebagaimana terjadi pada semester 1 tahun 2019 yang lalu, di tengah-tengah lesunya sektor property, sebagian besar perusahaan property memperoleh progres negatif pada pos pendapatan. Akan tetapi, hal sebaliknya terjadi pada pos laba bersih, dimana mayoritas perusahaan property justru mendapatkan pertumbuhan laba positif, bahkan ada yang berbalik untung (CNBC Indonesia, 2019). Hal ini tidak terlepas dari strategi manajemen perusahaan dalam mengatur kebutuhan dana operasionalnya. Perusahaan-perusahaan yang mencatatkan pertumbuhan laba bersih karena benar-benar mampu membatasi penggunaan pendapatan untuk investasi.

Untuk mendorong minat investor dalam menginvestasikan modalnya, perusahaan properti dituntut menyandang likuiditas yang baik. Keterjagaan kas pada keuangan perusahaan dapat mengatasi masalah likuiditas perusahaan.

Mengacu pada uraian di atas, maka perusahaan harus mengestimasi tingkat cash holding (kas ditangan) dengan baik. Penentuan kas ditangan pada suatu perusahaan bisa disebabkan dari berbagai faktor. Faktor yang dapat menjadi determinan yang mempengaruhi tingkat kas ditangan suatu perusahaan diantaranya ialah arus kas, modal kerja bersih, ukuran perusahaan, peluangan tumbuh, leverage, board size, dan arus konversi kas.

\section{TINJAUAN PUSTAKA}

Beberapa riset terdahulu dapat dikaji seperti dibawah :

1. Abdillah \& Kusumastuti (2014)

Menyatakan bahwa ukuran perusahaan (firm size), pembayaran dividen (dividend payment) dan ukuran dewan (board size) memiliki dampak yang signifikan pada corporate cash holding.

2. Masood dan Shah (2014) Menyatakan bahwa kepemilikan direksional dan ukuran dewan (board size) berdampak negatif pada cash holding perusahaan.

3. Senjaya dan Yadnyana (2015)

Menyatakan bahwa CCC, komisaris independen dan kepemilikan kelembagaan tidak berdampak pada cash holdings. 
4. Suherman (2017)

Hasil dari penelitian ialah modal kerja bersih dan sales growth berdampak positif signifikan atas cash holdings, sebaliknya ukuran perusahaan mempunyai dampak negatif signifikan. Sementara cash flow, CF variability, CCC, liquidity, dan leverage tidak berdampak atas cash holding.

5. Wijaya dan Bangun (2019)

Hasil dari riset menunjukan bahwa arus kas berdampak positif signifikan dan leverage berdampak negatif signifikan akan cash holding, dan ukuran perusahaan tidak berdampak signifikan atas cash holding.

Determinan menurut KBBI (2016: 348) berarti sebagai variabel yang menentukan. Riset ini dibatasi pada cash flow, cash conversion cycle, ukuran perusahaan, growth opportunity, leverage, board size, dan NWC.

1. $\mathrm{CHD}$

Kas ditangan adalah kas yang tersaji ataupun ditangguhkan di perusahaan dan digunakan untuk mendanai kebutuhan operasional, dana yang tidak terduga, dan investas perusahaan. Formula yang digunakan untuk menghitung :

CHD - $\frac{\text { Kas dan seliarakas }}{\text { Total Aset-Kas dan Setara Kas }}$

2. Arus Kas (CF)

Arus kas ialah arus masuk dan keluar kas atau setara kas pada perusahaan. Rumus untuk menghitung :

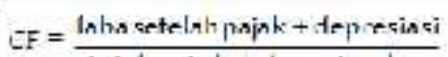

trtalaset-kasctansetnokins

3. Net Working Capital

Anwar (2019:30) mengemukakan: "Modal Kerja Bersih ialah jumlah atau total aktiva lancar dikurangi dengan total utang lancarnya." Rumus untuk menghitung :

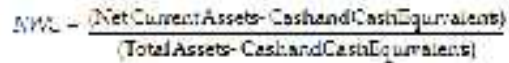

4. $\operatorname{Size}(F s)$

Ukuran perusahaan ialah skala pengukur dari makro maupun mikro suatu perusahaan dengan ketentuan tertentu dan akan berdampak atas besar kecilnya aliran kas operasional perusahaan. Rumus yang digunakan :

Size $=$ Ln Total Assets 
5. Growth OpportunityPeluang tumbuh (Growth opportunity) dapat dilihat sebagai kapabilitas suatu perusahaan untuk tumbuh maju di masa datang Rumus yang digunakan mengukur :

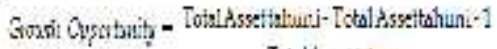

Tstalarceritilur.

6. Leverage

Laverage ialah penggunaan dana pinjaman oleh perusahaan guna meningkatkan hasil dari aktivitas investasi. Rumus untuk menghitung :

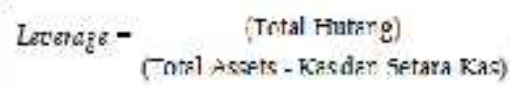

7. Board Size

Ukuran dewan merupakan total anggota dewan direksi dan komisaris dalam sebuah perusahaan. Rumus untuk menghitung :

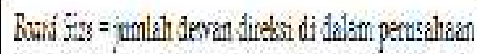

8. CCC

Siklus konversi kas (cash corversion cycle) ialah metrik yang digunakan untuk menghitung kesanggupan perusahaan untuk mengubah kas yang perusahaan miliki menjadi barang yang bisa dijual atau mendapatkan kas kembali. Rumus menghitung :

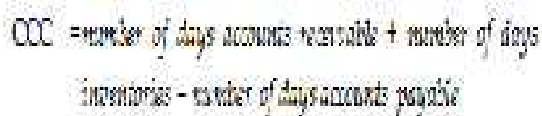

\section{KERANGKA KONSEPTUAL}

Untuk memperjelas hubungan dari variabel, kerangka konseptual bisa digambarkan seperti berikut :

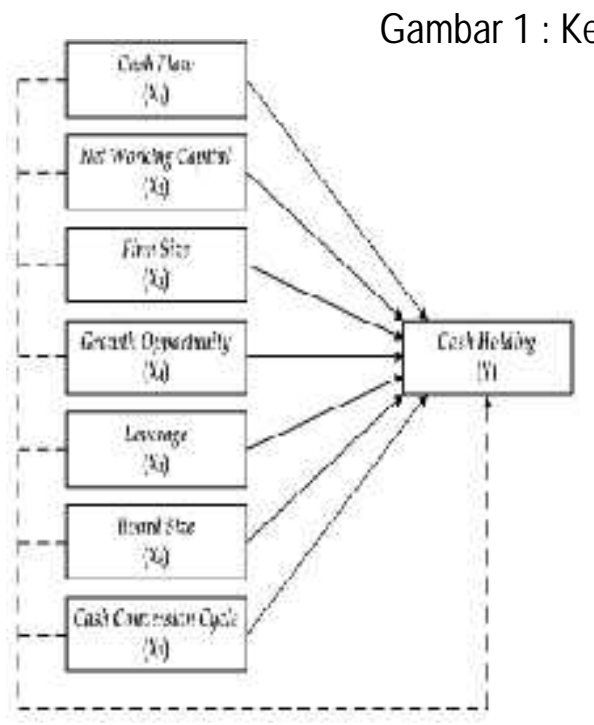


Keterangan Garis :

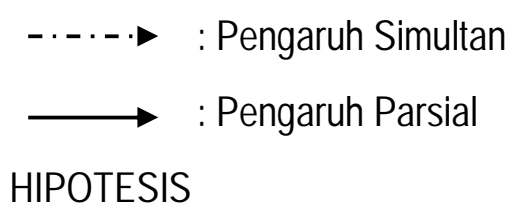

Spekulasi riset menunjukan informasi :

1. CF, NWC, ukuran perusahaan (firm size), peluang tumbuh (growth opportunity), leverage, board size, dan siklus konversi kas secara parsial berdampak pada kas ditangan.

2. Arus kas, Modal kerja bersih, firm size, peluang tumbuh, leverage, board size, dan siklus konversi kas secara simultan berdampak pada kas ditangan.

\section{METODE}

Jenis penelitian ini tergolong pada pengkajian kuantitatif. Teknik purposive sampling ialah cara pengutipan sampel yang digunakan. Basis data yang digunakan sekunder dengan metode dokumentasi berupa laporan keuangan perusahaan properti yang tercantum pada Bursa Efek Indonesia 2015-2019

\section{HASIL}

1. Dampak Arus kas pada Kas ditangan.

Hasil uji t, diperoleh nilai (Sig.) $=0,126>0,05$, sehingga arus kas secara parsial tidak berdampak signifikan pada kas ditangan (cash holding).

2. Dampak Net Working Capital pada Kas ditangan Hasil uji t, diperoleh nilai (Sig.) $=0,029<0,05$, sehingga Net Working Capital secara parsial berdampak signifikan pada kas ditangan.

3. Dampak ukuran perusahaan pada Cash Holding Hasil uji t, didapat (Sig.) = 0,744 >0,05, sehingga Firm size secara parsial tidak berdampak signifikan pada cash holding.

4. Dampak Growth Opportunity pada kas ditangan Hasil uji t, diperoleh nilai (Sig.) $=0,048<0,05$, sehingga growth opportunity secara parsial berdampak signifikan pada cash holding.

5. Dampak Leverage pada kas ditangan Hasil uji t, didapati (Sig.) $=0,000<0,05$, sehingga leverage secara parsial berdampak signifikan pada cash holding.

6. Dampak Board Size pada kas ditangan Hasil uji t, diperoleh nilai $($ Sig. $)=0,022<0,05$, sehingga board size secara parsial berdampak signifikan pada kas ditangan.

7. Dampak konversi arus kas pada Cash Holding Hasil uji t, diperoleh nilai (Sig.) =0,178 >0,05, sehingga cash conversion cycle secara parsial tidak berdampak signifikan pada cash holding. 
8. Hasil uji $F$, nilai (Sig.) $=0,001<0,05$, sehingga $\mathrm{H}_{0}$ ditolak dan $\mathrm{H}_{8}$ diterima. Menunjukkan bahwa arus kas (cash flow), modal kerja bersih (net working capital), ukuran perusahaan (firm size), peluang tumbuh, leverage, board size, dan konversi arus kas secara simultan berdampak pada cash holding.

\section{SIMPULAN}

Kesimpulan kajian ini adalah :

1. Arus kas, Ukuran perusahaan, dan Konversi arus kas secara parsial tidak berdampak signifikan pada cash holding.

2. Modal kerja bersih, Peluang tumbuh, Leverage, dan Board size secara parsial berdampak signifikan pada $\mathrm{CFH}$.

3. Arus kas (cash flow), Modal kerja bersih, Ukuran perusahaan, Peluang tumbuh, Leverage, Board Size, dan Konversi arus kas secara simultan berdampak signifikan pada Cash Holding.

\section{IMPLIKASI}

Penelitian ini menyampaikan penjelasan terkait variabel yang memiliki dampak pada tingkat cash holding, tiap variabel nantinya harus diperhatikan oleh perusahaan agar penetapan cash holding dapat dilakukan dengan baik

Kedepannya untuk riset berikutnya dapat memasukkan faktor lain yang tampaknya juga berdampak pada kas ditangan (cash holding).

Contohnya: capital expenditure, profitabilitas, Corporate Governance, nilai perusahaan, dividend payment.

\section{KETERBATASAN PENELITIAN}

Hasil riset ini memiliki dependensi, yaitu :

1. Subjek membatasi meneliti pada tahun 2015-2019 berdasarkan data perusahaan yang tercatat pada Bursa Efek Indonesia

2. Terbatasnya sampel penelitian.

3. Menggunakan data sekunder yang dalam dalam proses input mungkin terjadi banyak kesalahan. 


\section{DAFTAR RUJUKAN}

Bursa Efek Indonesia. 2020. Anggota Bursa \& Partisipan. Diakses dari http://www.idx.co.id. pada Maret 2020.

Ghozali, Imam. 2018. Aplikasi Analisis Multivariate dengan Program IBM SPSS 25. Edisi Sembilan. Semarang: Universitas Diponegoro.

Gujarati. 2018. Ekonometrika Dasar. Edisi Bahasa Indonesia. Penerjemah Sumarno Zain. Jakarta: Erlangga.

Hartono, Jogiyanto. 2013. Teori Portofolio dan Analisis Investasi. Yogyakarta: BPFE.

Kasmir. 2014. Pengantar Manajemen Keuangan. Jakarta: Prenadamedia Group.

Keown, A. J., Martin, F. D. Petty, J. W., dan Scott, D. F. 2010. Dasar-Dasar Manajemen Keuangan. Buku 2. Jakarta: Salemba Empat.

Noor, Juliansyah. 2017. Metodologi Penelitian. Jakarta: Kencana.

Riyanto, Bambang. 2015. Dasar-Dasar Pembelanjaan Perusahaan. Edisi keempat. Penerbit: BPFE, Yogyakarta.

Sugeng, Bambang. 2019. Manajemen Keuangan Fundamental. Yogyakarta: Deepublish Publsher.

Sugiyono. 2017. Metode Penelitian Kuantitatif, Kualitatif dan R\&D. Bandung: Alfabeta.

Abdillah, Fajar dan Kusumastuti, Retno. 2014. Pengaruh Karakteristik Perusahaan dan Board Size Terhadap Corporate Cash Holding. Jurnal FISIP UI. Vol. 1. No. 2. hal. 1-18. 